\title{
Factors associated with metabolic syndrome in older adults: a population-based study
}

\author{
Fatores associados à síndrome metabólica em idosos: estudo de base populacional
}

Los factores asociados con el síndrome metabólico en adultos mayores: un estudio de base poblacional

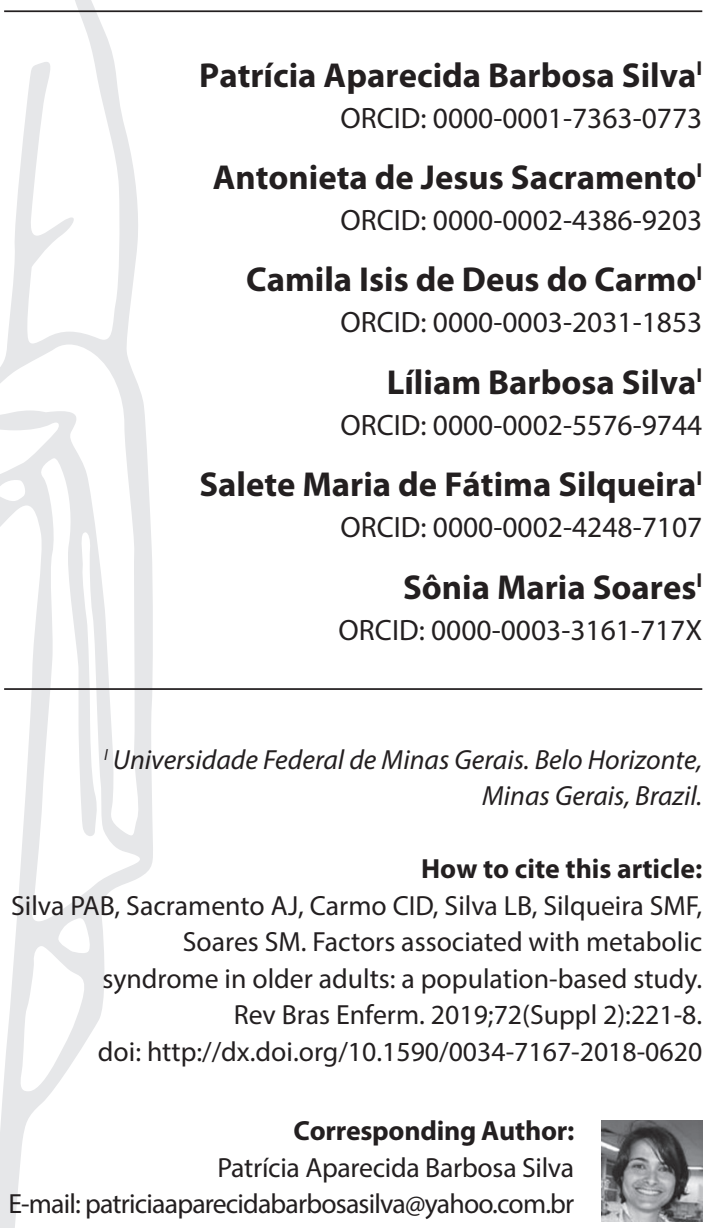

Submission: $07-24-2018$

Approval: 09-13-2018

\begin{abstract}
Objective: To estimate the prevalence of the metabolic syndrome and clusters of its components and to identify possible associated factors in older adults. Method: Cross-sectional and population-based study, involving 271 older people. We collected sociodemographic, behavioral, clinical, biochemical, and anthropometric data. Data were analyzed by descriptive and logistic regression techniques. Results: The prevalence of metabolic syndrome was $59 \%$ and was associated with women, overweight/obesity, and the C-reactive protein. Concerning the clusters, $11.4 \%$ of the sample had all the components of the metabolic syndrome, and only $5.2 \%$ of individuals did not have any of its components. Conclusion: We found there is a high prevalence of metabolic syndrome and clusters of its components in older adults. It is important to deepen studies on this matter, considering clinical aspects in relation to sex and healthy behavioral habits for creating public policies as well as emphasizing actions aimed at promoting self-care in all cycles of life.
\end{abstract}

Descriptors: Aging; Health of the Elderly; Metabolic Syndrome; Risk Factors; Nursing.

\section{RESUMO}

Objetivo: Estimar a prevalência de síndrome metabólica e de aglomerados de seus componentes e identificar possíveis fatores associados em pessoas idosas. Método: Estudo transversal, de base populacional, envolvendo 271 idosos. Foram coletados dados sociodemográficos, comportamentais, clínicos, bioquímicos e antropométricos. Os dados foram analisados por meio de técnicas descritivas e de regressão logística. Resultados: A prevalência de síndrome metabólica foi de $59 \%$ e associou-se ao sexo feminino, a sobrepeso/ obesidade e à proteína C-reativa. Sobre os aglomerados, $11,4 \%$ da amostra possuía a totalidade dos componentes da síndrome metabólica, e apenas 5,2\% dos indivíduos não possuíam nenhum de seus componentes. Conclusão: Constatou-se elevada prevalência de síndrome metabólica em idosos e de aglomerados de seus componentes. É importante aprofundar estudos sobre esta temática, considerando aspectos clínicos em relação ao sexo e a hábitos comportamentais saudáveis para formulação de políticas públicas, além de enfatizar ações que visem fomentar o autocuidado em todos os ciclos de vida.

Descritores: Envelhecimento; Saúde do Idoso; Síndrome Metabólica; Fatores de Risco; Enfermagem.

\section{RESUMEN}

Objetivo: Evaluar la prevalencia del síndrome metabólico y el conglomerado de sus componentes e identificar los posibles factores asociados en personas de edad avanzada. Método: Estudio de tipo transversal, de base poblacional, en el cual participaron 271 adultos mayores. Se recogieron los datos sociodemográficos, conductuales, clínicos, bioquímicos y antropométricos. Se analizaron los datos por medio de técnicas descriptivas y de regresión logística. Resultados: La prevalencia del síndrome metabólico fue del 59\% y se la asoció con el sexo femenino, el sobrepeso/obesidad y la proteína $\mathrm{C}$ reactiva. En los conglomerados, el $11,4 \%$ de la muestra presentaba todos los componentes del síndrome metabólico, y sólo el 5,2\% no los tenía. Conclusión: Los hallazgos demuestran una alta prevalencia del síndrome metabólico y de conglomerados de sus componentes en los adultos mayores. Son necesarios más estudios sobre este tema, considerando los aspectos clínicos en lo referente al sexo y los hábitos saludables, para establecer políticas públicas saludables, así como enfatizar acciones dirigidas a promover el autocuidado en todos los ciclos de la vida.

Descriptores: Envejecimiento; Salud del Anciano; Síndrome Metabólico; Factores de Riesgo; Enfermería. 


\section{INTRODUCTION}

In the last three decades, the metabolic syndrome (MS) has outstood as an important public health issue ${ }^{(1)}$. Despite the lack of consensus on the definition of MS, in the literature the coexistence of three or more cardiometabolic risk factors is commonly accepted such as abdominal obesity, hyperglycemia or insulin resistance, hypertension, hypertriglyceridemia, and reduction of serum levels of high density lipoprotein cholesterol (HDL-c) ${ }^{(2)}$. Several studies have addressed the association between MS and increased risk of mortality ${ }^{(3)}$, cardiovascular events, type 2 diabetes mellitus ${ }^{(4-5)}$, mild cognitive impairment, and progression to dementia ${ }^{(6)}$, with greater clinical repercussions for older people ${ }^{(3)}$.

The prevalence of MS is high worldwide, and increases with aging, ranging from $22.7 \%$ in $\mathrm{Brazi}^{\left({ }^{(7)}\right.}, 24.3 \%$ in European countries ${ }^{(8)}$, and $34.2 \%$ in the United States of America ${ }^{(9)}$. The divergence of these estimates is partly explained by the influence of different diagnostic criteria of this syndrome as well as by regional differences and the sample profile (age, sex, race/ethnicity, and socioeconomic status) $)^{(1,4)}$.

In a recent systematic review ${ }^{(10)}$, Moore, Chaudhary, and Akinyemiju questioned if MS is a construct suitable for older adults, based on previous research according to which the global prognostic value of MS in older people does not mean that such is superior to individual risk factors separately considered. The authors even suggested the need to generalize the diagnostic criteria of MS, adjusted by age group, including the definition of ideal metabolic goals for the geriatric population.

Despite the discussion on the definition of MS and on specific cut-off points for age, according to the literature there is a growing trend of new cases of MS due to population aging, increasing obesity, excessive intake of obesogenic foods, and sedentary lifestyle ${ }^{(11)}$. In addition to its importance as an epidemiological event, authors of a study ${ }^{(12)}$ held in Tel Aviv, Israel, point to the probable misdiagnosis of MS as a result of lack of knowledge and familiarity of health professionals to identify and classify people with the syndrome. This is an important issue to be highlighted, since failures in the handling of MS symptoms can cause worse prognosis, doubling the chances of developing cardiovascular events ${ }^{(1)}$ and increasing the risk of mortality due to all causes and cardiovascular diseases in about $23 \%$ and $24 \%$, respectively, when compared with the risk of those who did not meet the criteria for $\mathrm{MS}^{(3)}$.

This is because continued exposure to several risk factors, particularly psychosocial stress, in addition to the consumption of an inadequate diet (rich in fats and sugars, very linked to processed foods, and poor in fruits and vegetables), smoking, abusive consumption of alcoholic beverages, and the sedentary lifestyle, leads directly or indirectly to the pathogenesis of cardiovascular diseases, with early reduction of people's productive life. Hence, the chronic exposure to these factors is believed to reduce biological resilience, in such a way to affect the physiological balance of the body, contributing to the development of $\mathrm{MS}^{(13)}$.

Therefore, we perceive that the control of MS is challenging, since, when associated especially with modifiable risk factors, patients are required to change their lifestyle, and on the part of healthcare professionals, they should change their actions based on continuous health care aimed at these individuals. Thus, we highlight the work of nurses who, being trained to develop education actions in health care, face as the biggest challenge the need to develop strategies aiming to guide the individual to self-care and the consequent adherence to treatment ${ }^{(14)}$.

Furthermore, even if it is widely known that the prevalence of MS increases with age, regardless of its definition ${ }^{(15)}$, studies on the risk factors associated with MS directed to the older population are still incipient, justifying the performance of our study.

\section{OBJECTIVE}

To estimate the prevalence of metabolic syndrome and clusters of its components and identify possible associated factors in older adults.

\section{METHOD}

\section{Ethical aspects}

The study is in line with resolution no. $466 / 2012^{(16)}$ and was approved by the Research Ethics Committee of Universidade Federal de Minas Gerais and by the Ethics Committee of the Municipal Department of Health of the city of Belo Horizonte, state of Minas Gerais. All participants signed the informed consent form, thus ensuring data confidentiality and anonymity.

\section{Study design, location, and period}

This is a cross-sectional, population-based study, conducted within the regional scope, on older adults living in one of nine health districts of Belo Horizonte, Minas Gerais, Brazil. Data were gathered from a secondary database, based on a major study entitled Envelhecimento e Doença Renal [Aging and Kidney Disease] (en-DoRen) ${ }^{(17)}$, and collected in the period from August 26, 2014 to November 1st, 2016.

\section{Sample and selection criteria}

The baseline of the en-DoRen study is composed of 300 older people. In our analysis, we considered as inclusion criteria individuals aging 60 years or older, according to the definition of older adults of the Brazilian legislation ${ }^{(18)}$, living in different households of the study district. As exclusion criteria, we considered having severe cognitive impairment (score in Mini-mental State Examination - MMSE $\leq$ 9), when there was no presence of a person responsible for assisting in the answers of the questionnaire. Was considered as loss those individuals with absence of information in at least one of the criteria for the MS definition. After meeting the inclusion and exclusion criteria, the sample was limited to 271 older adults, since 29 of the participants did not have dosage of serum triglycerides and HDL-c.

For sample calculation, we used the method proposed by Lwanga and Lemeshow ${ }^{(19)}$ in order to verify if the number of individuals of this analysis is sufficient to assess the prevalence of MS. To do so, we used a conservative criterion, whose prevalence was considered $50 \%$, which is the maximum sample size variability, absolute accuracy of $7 \%$, and a significance level of $5 \%$, resulting in a minimum $n$ of 196 individuals. Considering $10 \%$ of possible losses, the final estimate $n$ consisted of 216 individuals.

The gathering of older people was based on the method of probability sampling, with simple random selection of households 
by drawing, from a table of random numbers based on proportional distribution of the number of households $(62,800)$ in each urban census sector (461). Were excluded from the sample areas of high risk and high rate of violence (91 census sectors and 16,440 households) due to the difficulty of researchers'stay in these locations. Therefore, remained in the study 46,360 households distributed among 370 census sectors. We highlight that 140 census sectors were grouped into a single sector due to low participation percentage in the region under study, accounting for a total of 5,604 households ${ }^{(17)}$.

\section{Study protocol}

The field work was carried out by two nurses and researchers, and six scientific research scholarship students, all previously trained. We carried out a household survey, with the application of a semi-structured and pretest questionnaire, containing sociodemographic, behavioral, clinical, and laboratory data. Later, blood pressure was measured and anthropometric data were collected, within a maximum interval of two weeks after the interview, and the day of collection of the biological material was scheduled. Venipuncture was performed at the households, by two of the authors of this study, for determining biochemical parameters of interest, with the participants in 12-hour fasting. The biological material was forwarded at the same day of the collection for the dependencies of a clinical analysis laboratory in which the processing and issuing of the examination report would be carried out.

The dependent variable was MS, defined according to the criterion of the revised National Cholesterol Education Program Adult Treatment Panel III (NCEP ATP III) ${ }^{(20)}$, considered as the most widely used guideline in clinical practice due to its simplicity and strong clinical evidence ${ }^{(21)}$. According to the revised NCEP ATP III (20), MS is characterized by the presence of three or more of the following five criteria: high triglycerides (TG $\geq 150 \mathrm{mg} /$ $\mathrm{dL}$ and/or use of fibrates), low HDL-c $(<40 \mathrm{mg} / \mathrm{dL}$ for men, and $<50 \mathrm{mg} / \mathrm{dL}$ for women and/or use of fibrates), high waist circumference ( $\geq 102 \mathrm{~cm}$ for men, and $\geq 88 \mathrm{~cm}$ for women), high blood pressure levels (systolic blood pressure - SBP $\geq 130 \mathrm{mmHg}$ and/or diastolic blood pressure - DBP $\geq 85 \mathrm{mmHg}$ and/or use of antihypertensive), high glucose levels in fasting (Glc $\geq 100 \mathrm{mg} /$ $\mathrm{dL}$ and/or prior diagnosis of diabetes mellitus).

Later, we defined as clusters of MS components the presence of any combination of the five criteria of MS aforementioned, categorized according to the number of exposure to such components $(0=$ none; $1=$ presence of one component; $2=$ presence of two components; 3 = presence of three components; $4=$ presence of four components; and 5 = presence of five components).

Independent variables consisted of sociodemographic and behavioral characteristics, health conditions, and biochemical parameters. The first set of variables consisted of sex (female; male); age in years (60-64; $65-74 ; 75$ or over); and education level, also in years ( $0-4 ; 5$ or over). On the other hand, the set of behavioral characteristics consisted of the variables: smoking (no; current smoker; former smoker); alcoholism, measured by the questionnaire The AlcoholUse Disorders Identification Test-Consumption (AUDIT-C) ${ }^{(22)}$ (score $\geq 4$ for men and $\geq 3$ for women suggests likely abuse of alcohol beverages); and sedentary lifestyle (physical activity practice for less than 30 minutes and often less than three times a week). Concerning health conditions, it consisted of variables: cognitive level, assessed by the MMSE and adjusted according to the education level(23) (changed cognitive level to score $\leq 13$ if illiterate; score $\leq 18$ if $\leq 8$ years of education; score $\leq 26$ if $>8$ years of education), and overweight/obesity, based on specific cut-off points of body mass index (BMI) for older adults ${ }^{(24)}$ (overweight: $27-30 \mathrm{~kg} / \mathrm{m}^{2}$ for men and $27-32 \mathrm{~kg} / \mathrm{m}^{2}$ for women; obesity: $>30 \mathrm{~kg} / \mathrm{m}^{2}$ for men and $>32 \mathrm{~kg} / \mathrm{m}^{2}$ for women). The last set of variables concerns biochemical parameters, which were categorized according to the reference values: C-reactive protein (CRP $\leq 3 \mathrm{mg} / \mathrm{L})$, uric acid $(<7.3 \mathrm{mg} / \mathrm{dL}$ for men and $<6.1 \mathrm{mg} / \mathrm{dL}$ for women), total cholesterol $(<200 \mathrm{mg} / \mathrm{dL})$, and LDL-c ( $<160 \mathrm{mg} / \mathrm{dL})$.

\section{Data analysis and statistics}

In data analysis, frequencies and ratios were reported for categorical variables; median and interquartile range (IQR), for non-parametric continuous variables. Normality analysis of continuous variables was performed by the Kolmogorov-Smirnov test. Percentages were compared using the Pearson's Chi-square test or the Fisher's exact test.

In univariate analysis, we considered a critical level of $p$-value $<0.20$ to enter in the multivariate model. Logistic regression with forced entry (enter) was designed to assess the direction and magnitude of associations of each independent variable with the response variable (MS). In this analysis, $p<0.05$ was deemed statistically significant. Obtained values were expressed as odds ratio (OR), and their respective $95 \%$ confidence intervals $(95 \%$ $\mathrm{Cl}$ ). The fit of the final model was evaluated by the goodness-offit test. In all analyses, we used the Statistical Package for Social Sciences program (SPSS, version 23, Chicago, IL, USA).

\section{RESULTS}

The sample was made up of 271 older adults, mostly women (67.5\%), median age of 71 years old (IQ: 65-79 years). Approximately half of participants had up to four years of study (49.1\%). Regarding behavioral habits, $10.3 \%$ of the sample were smokers; $17.7 \%$ had likely abuse of alcoholic beverages; and $67.9 \%$ did not practice physical activity. As for clinical aspects, 50.6\% were above the ideal weight, and $12.5 \%$ had cognitive changes. As for laboratory parameters, the analyte with biggest change was CRP (42.1\%), followed by the total cholesterol (30.6\%) (data not shown).

The prevalence of MS was 59.0\% (95\% Cl: 53.2-64.9\%). In univariate analysis, MS was associated with women (OR: $2.45 ; 95 \% \mathrm{Cl}$ : 1.46-4.13), current smoking (OR:0.40; 95\% Cl:0.18-0.91), overweight/ obesity (OR: 5.07; 95\% Cl: 2.99-8.59), high CRP levels (OR: 3.20; 95\% Cl: 1.90-5.42), and hyperuricemia (OR: $2.21 ; 95 \%$ Cl: 1.15-4.22) (Table 1).

After adjustment for potential confounding factors, remained in the multivariate model associated with the outcome: female sex (OR: 1.87; 95\% Cl: 1.06-3.30), overweight/obesity (OR: 3.89; 95\% Cl: 2.23-6.77), and high CRP levels (OR: $2.03 ; 95 \% \mathrm{Cl}: 1.14-3.59)$. The fit of the model was satisfactory (Prob>chi2 $=0.9203$ ) (Table 2 ).

In relation to the clusters of MS components, we observed that $11.4 \%$ of the sample featured all the components. Only $5.2 \%$ of participants did not meet any of the five criteria for MS, this being data statistically different between sexes $(p=0.016)$. There was a trend of higher percentage of clusters of MS components among women compared with men (Figure 1). 
Table 1 - Baseline characteristics of participants related to metabolic syndrome according to the revised National Cholesterol Education Program Adult Treatment Panel III criteria, Belo Horizonte, Minas Gerais, Brazil, 2014-2016

\begin{tabular}{|c|c|c|c|c|}
\hline Variables & $\begin{array}{c}\text { No } \\
n(\%)\end{array}$ & $\begin{array}{c}\text { Yes } \\
n(\%)\end{array}$ & $\mathrm{OR}_{\text {crude }}(95 \% \mathrm{Cl})$ & $p$ value ${ }^{*}$ \\
\hline \multicolumn{5}{|l|}{ Sex } \\
\hline Male & $49(44.1)$ & $39(24.4)$ & 1.00 & \\
\hline Female & $62(55.9)$ & $121(75.6)$ & $2.45(1.46-4.13)$ & 0.001 \\
\hline \multicolumn{5}{|l|}{ Age group ${ }^{\text {(years) }}$} \\
\hline $60-64$ & $29(26.1)$ & $34(21.3)$ & 1.00 & \\
\hline $65-74$ & 34 (30.6) & $71(44.4)$ & $1.78(0.94-3.39)$ & 0.078 \\
\hline 75 or over & $48(43.2)$ & $55(34.4)$ & $0.98(0.52-1.83)$ & 0.943 \\
\hline \multicolumn{5}{|l|}{ Education level(years) } \\
\hline $0-4$ & $54(48.6)$ & $79(49.4)$ & $1.03(0.63-1.67)$ & 0.906 \\
\hline 5 or over & $57(51.4)$ & $81(50.6)$ & 1.00 & \\
\hline \multicolumn{5}{|l|}{ Smoking } \\
\hline Non-smoker & $62(55.9)$ & $100(62.5)$ & 1.00 & \\
\hline Current smoker & $17(15.3)$ & $11(6.9)$ & $0.40(0.18-0.91)$ & 0.029 \\
\hline Former smoker & $32(28.8)$ & $49(30.6)$ & $0.95(0.55-1.64)$ & 0.852 \\
\hline \multicolumn{5}{|l|}{ AUDIT-C scores } \\
\hline$<3(\mathrm{~F})$ and $<4(\mathrm{M})$ & $90(81.1)$ & $133(83.1)$ & 1.00 & \\
\hline$\geq 3(\mathrm{~F})$ and $\geq 4(\mathrm{M})$ & $21(18.9)$ & $27(16.9)$ & $0.87(0.46-1.63)$ & 0.665 \\
\hline \multicolumn{5}{|l|}{ Sedentary lifestyle } \\
\hline No & $38(34.2)$ & 49 (30.6) & 1.00 & \\
\hline Yes & $73(65.8)$ & $111(69.4)$ & $1.18(0.70-1.98)$ & 0.532 \\
\hline \multicolumn{5}{|l|}{ Overweight/obesity } \\
\hline No & $80(72.1)$ & $54(33.8)$ & 1.00 & \\
\hline Yes & $31(27.9)$ & $106(66.3)$ & $5.07(2.99-8.59)$ & $<0.001$ \\
\hline \multicolumn{5}{|l|}{ Cognitive level } \\
\hline Preserved & $96(86.5)$ & $141(88.1)$ & 1.00 & \\
\hline Changed & $15(13.5)$ & $19(11.9)$ & $0.86(0.42-1.78)$ & 0.689 \\
\hline \multicolumn{5}{|l|}{$\mathrm{CRP}(\mathrm{mg} / \mathrm{L})$} \\
\hline$\leq 3.0$ & $82(73.9)$ & $75(46.9)$ & 1.00 & \\
\hline$>3.0$ & $29(26.1)$ & $85(53.1)$ & $3.20(1.90-5.42)$ & $<0.001$ \\
\hline \multicolumn{5}{|l|}{ Uric acid $^{(\mathrm{mg} / \mathrm{dL})}$} \\
\hline$<7.3 \mathrm{M}$ and $<6.1 \mathrm{~F}$ & $96(86.5)$ & $119(74.4)$ & 1.00 & \\
\hline$\geq 7.3 \mathrm{M}$ and $\geq 6.1 \mathrm{~F}$ & $15(13.5)$ & 41 (25.6) & $2.21(1.15-4.22)$ & 0.017 \\
\hline \multicolumn{5}{|l|}{ Total cholesterol(mg/dL) } \\
\hline$<200$ & $80(72.1)$ & $108(67.5)$ & 1.00 & \\
\hline$\geq 200$ & $31(27.9)$ & $52(32.5)$ & $1.24(0.73-2.11)$ & 0.422 \\
\hline \multicolumn{5}{|l|}{ LDL-- ${ }^{(m g / d L)^{* * *}}$} \\
\hline$<160$ & $100(90.1)$ & $144(90.6)$ & 1.00 & \\
\hline$\geq 160$ & $11(9.9)$ & $15(9.4)$ & $0.95(0.42-2.15)$ & 0.896 \\
\hline
\end{tabular}

Note: ${ }^{*} p<0.05$ (Pearson's Chi-square test or Fisher's exact test). * ${ }^{*}$ Missing information ( $n=1$ ). AUDIT-C: Alcohol Use Disorders Identification Test-Consumption. F: Female. $95 \%$ Cl: $95 \%$ Confidence Interval. LDL-c: Low Density Lipoprotein Cholesterol. M: Male. OR: Odds Ratio. CRP: C-Reactive Protein.

Table 2 - Final logistic regression model for prevalence of metabolic syndrome according to the revised National Cholesterol Education Program Adult Treatment Panel III criteria, Belo Horizonte, Minas Gerais, Brazil, 2014-2016

\begin{tabular}{lcc}
\hline \multirow{2}{*}{ Variables } & \multicolumn{2}{c}{ Metabolic syndrome } \\
& OR $_{\text {ajustado }}(\mathbf{9 5 \%} \mathbf{C l})$ & $\boldsymbol{p}$ value \\
\hline Sex & & \\
$\quad$ Male & 1.00 & \\
$\quad \begin{array}{l}\text { Female } \\
\text { Overweight/obesity } \\
\text { No } \\
\text { Yes }\end{array}$ & $1.87(1.06-3.30)$ & 0.031 \\
CRP(mg/L) & 1.00 & \\
$\leq 3,0$ & $3.89(2.23-6.77)$ & $<0.001$ \\
$>3,0$ & 1.00 & \\
& $2.03(1.14-3.59)$ & 0.016
\end{tabular}

Note: 95\% Cl: 95\% Confidence Interval. OR: Odds Ratio. CRP: C-Reactive Protein. Prob $>$ chi2 = 0.9203 (fit of the satisfactory model).

In addition, we observed that the component that most contributed to the presence of MS was hypertension (83.8\%), followed by high waist circumference (67.2\%). By stratifying the five components of MS per sex, we identified higher prevalence of low
HDL-c and high waist circumference among women compared with men (Figure 2).



Note: * $p<0.05$ (Pearson's Chi-square test or Fisher's exact test).

Figure 1 - Distribution of the number of components of the metabolic syndrome based on the revised National Cholesterol Education Program Adult Treatment Panel III, stratified per sex, Belo Horizonte, Minas Gerais, Brazil, 2014-2016 


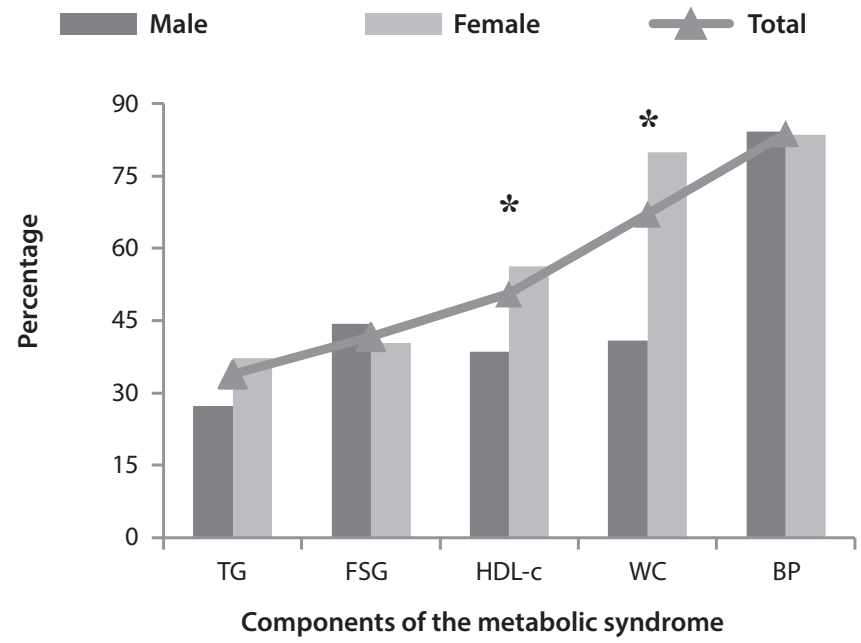

Note: * $p<0.05$ (Pearson's Chi-square test or Fisher's exact test). BP: Blood Pressure. FSG: Fasting Serum Glucose. HDL-c: High Density Lipoprotein Cholesterol. TG: Triglycerides. WC: Waist Circumference.

Figure 2 - Distribution of the types of components of the metabolic syndrome based on the revised National Cholesterol Education Program Adult Treatment Panel III, stratified per sex, Belo Horizonte, Minas Gerais, Brazil, 2014-2016

The most frequent combination between MS components was triglycerides, HDL-c, waist circumference, high blood pressure, and fasting serum glucose (19.4\%), followed by the combination of HDL-C, waist circumference, and high blood pressure (16.9\%). Further details of combinations stratified per sex are listed in Table 3.

Table 3 - Combinations of components of the metabolic syndrome based on the revised National Cholesterol Education Program Adult Treatment Panel III criteria, stratified per sex, Belo Horizonte, Minas Gerais, Brazil, 2014-2016

\begin{tabular}{|c|c|c|c|c|c|c|c|}
\hline \multirow[t]{2}{*}{ Combinations } & \multicolumn{2}{|c|}{$\begin{array}{c}\text { Total } \\
(\mathrm{N}=160)\end{array}$} & \multicolumn{2}{|c|}{$\begin{array}{c}\text { Male } \\
(n=39)\end{array}$} & \multicolumn{2}{|c|}{$\begin{array}{l}\text { Female } \\
(n=121)\end{array}$} & \multirow[t]{2}{*}{$p$ value } \\
\hline & $\mathbf{n}$ & $\%$ & $\mathbf{n}$ & $\%$ & $\mathrm{n}$ & $\%$ & \\
\hline
\end{tabular}

\begin{tabular}{|c|c|c|c|c|c|c|c|}
\hline \multicolumn{8}{|l|}{5 components } \\
\hline $\mathrm{TG}+\mathrm{HDL}-\mathrm{c}+\mathrm{WC}+\mathrm{BP}+\mathrm{FSG}$ & 31 & 19.4 & 6 & 15.4 & 25 & 20.7 & 0.468 \\
\hline \multicolumn{8}{|l|}{4 components } \\
\hline $\mathrm{TG}+\mathrm{HDL}-\mathrm{c}+\mathrm{WC}+\mathrm{FSG}$ & 4 & 2.5 & 0 & 0.0 & 4 & 3.3 & 0.573 \\
\hline $\mathrm{TG}+\mathrm{HDL}-\mathrm{c}+\mathrm{BP}+\mathrm{FSG}$ & 7 & 4.4 & 5 & 12.8 & 2 & 1.7 & 0.010 \\
\hline $\mathrm{TG}+\mathrm{WC}+\mathrm{BP}+\mathrm{FSG}$ & 10 & 6.3 & 4 & 10.3 & 6 & 5.0 & 0.259 \\
\hline $\mathrm{TG}+\mathrm{HDL}-\mathrm{c}+\mathrm{WC}+\mathrm{BP}$ & 15 & 9.4 & 3 & 7.7 & 12 & 9.9 & 1.000 \\
\hline $\mathrm{HDL}-\mathrm{c}+\mathrm{WC}+\mathrm{BP}+\mathrm{FSG}$ & 19 & 11.9 & 3 & 7.7 & 16 & 13.2 & 0.569 \\
\hline \multicolumn{8}{|l|}{3 components } \\
\hline $\mathrm{TG}+\mathrm{WC}+\mathrm{FSG}$ & 1 & 0.6 & 0 & 0.0 & 1 & 0.8 & 1.000 \\
\hline $\mathrm{TG}+\mathrm{BP}+\mathrm{FSG}$ & 2 & 1.3 & 2 & 5.1 & 0 & 0.0 & 0.058 \\
\hline $\mathrm{TG}+\mathrm{HDL}-\mathrm{C}+\mathrm{BP}$ & 3 & 1.9 & 0 & 0.0 & 3 & 2.5 & 1.000 \\
\hline $\mathrm{HDL}-\mathrm{C}+\mathrm{WC}+\mathrm{FSG}$ & 3 & 1.9 & 0 & 0.0 & 3 & 2.5 & 1.000 \\
\hline $\mathrm{TG}+\mathrm{HDL}-\mathrm{c}+\mathrm{WC}$ & 4 & 2.5 & 0 & 0.0 & 4 & 3.3 & 0.573 \\
\hline $\mathrm{TG}+\mathrm{WC}+\mathrm{BP}$ & 8 & 5.0 & 1 & 2.6 & 7 & 5.8 & 0.681 \\
\hline $\mathrm{HDL}-\mathrm{c}+\mathrm{BP}+\mathrm{FSG}$ & 10 & 6.3 & 8 & 20.5 & 2 & 1.7 & $<0.001$ \\
\hline $\mathrm{WC}+\mathrm{BP}+\mathrm{FSG}$ & 16 & 10.0 & 5 & 12.8 & 11 & 9.1 & 0.542 \\
\hline $\mathrm{HDL}-\mathrm{C}+\mathrm{WC}+\mathrm{BP}$ & 27 & 16.9 & 2 & 5.1 & 25 & 20.7 & 0.026 \\
\hline
\end{tabular}

Note: ${ }^{*} p<0.05$ (Pearson's Chi-square test or Fisher's exact test). BP:Blood Pressure. FSG: Fasting Serum Glucose. HDL-c: High Density Lipoprotein Cholesterol. TG: Triglycerides. WC: Waist Circumference.

\section{DISCUSSION}

We identified a high prevalence of MS (59.0\%) in a representative sample of older people, defined by the revised NCEP ATP III criteria. This finding corroborates a previous study ${ }^{(25)}$, conducted in Goiânia
(GO), Brazil, involving older adults users of primary healthcare services, with the same diagnostic criteria (58.7\%). In other Brazilian studies, the prevalence of MS was discrepant, ranging from $22.7 \%$ to $69.1 \%(7,21,26)$, as well as in studies carried out in Mexico (36.0-52.0\%) ${ }^{(27)}$ and in Portugal(36.5-49.6\%) ${ }^{(28)}$. These differences in the epidemiological pattern of the MS are mainly due to the inclusion of younger people in the sample and/or the use of different diagnostic criteria, in addition to regional and cultural differences.

In addition, there is high accumulation of MS components per individual, and approximately one-third of the sample had four or five components - which is worrisome in terms of public health, considering the synergistic effect between the clusters of cardiometabolic risk factors. In this regard, more than a decade ago authors of the traditional INTERHEART study ${ }^{(29)}$, conducted in 52 diverse countries of the five habitable continents, demonstrated synergism between MS components, which enhances the risk of cardiovascular events. In isolation, the presence of diabetes mellitus and hypertension increases the chances of acute myocardial infarction in 2.4 and 1.9 times, respectively. When the individual manifested these two components at the same time, in addition to smoking, chances increased to $13.0 \%$. If we consider lipid disorder and abdominal obesity, the chance would quintuple $(68.5 \%)$ ${ }^{(29)}$. Moreover, authors of a recent study ${ }^{(30)}$ conducted on 159,971 Korean adults showed a linear association between the number of MS components and the relative risk of cardiovascular mortality, from 1.99 (1 component) to 2.98 (4-5 components), and diabetes mellitus and hypertension contributed the most to the increase in mortality.

Despite the uncertainty about the definition of MS, there is a consensus in literature of the importance of the individual clinical surveillance of its components, with emphasis on the geriatric population, in which adverse effects are more intense due to their greater fragility and the coexistence of multiple chronic conditions ${ }^{(3-4)}$. Moreover, even those individuals who do not meet all the criteria of MS, but have at least one of the components of this syndrome, have increased risk of developing cardiovascular events and type 2 diabetes mellitus when compared with those with no risk factors for MS, according to a previous study ${ }^{(5)}$.

In its turn, factors associated with MS, including sex, overweight/obesity, and CRP, were also identified in our study. There is scientific evidence that the prevalence of MS is more pronounced with increasing age, being more frequent in women aging 50 years or over ${ }^{(2,21,28)}$. A possible explanation is attributed to estrogen deficiency during the ovarian failure in menopause, which contributes to the appearance of some risk factors, such as insulin resistance, abdominal obesity, increased triglycerides, and reduction of HDL$\mathrm{C}^{(2)}$, in addition to increased arterial stiffness, more pronounced in women of this age $\mathrm{e}^{(31)}$. We find other factors in the literature, distinguishing sex-related factors such as the greater propensity of women in developing MS in response to stress of the working environment, low socioeconomic status, and education level (2). 
In our study, the prevalence of MS was approximately four times higher in older people with overweight (overweight/obesity) in relation to the reference group. This is a worrying data, since estimates of the NCD Risk Factor Collaboration ${ }^{(32)}$ indicate a worldwide trend of the increasing prevalence of obese subjects (BMI $\geq 30 \mathrm{~kg} /$ $\mathrm{m}^{2}$ ) in all age groups, reaching percentages of $18 \%$ for men and $21 \%$ for women in the year 2025. In particular, Brazil is among the five countries with the highest number of obese people $(11.9 \%$ men and $18.0 \%$ women), including severe obesity ( $2.2 \%$ men and $6.7 \%$ women) $)^{(32)}$. About two-thirds of the Brazilian population will be overweight and a quarter will be obese within a decade, undermining to achieve one of the Millennium Development Goals ${ }^{(33)}$.

As for the physiopathological relationship between obesity and MS, according to the literature the primary disturbances in the energy balance produced by obesity, especially the visceral adiposity, are enough to trigger all components of this syndrome. To illustrate this argument, we highlight that the change in metabolism of the free fatty acids induces insulin resistance and stimulates the synthesis of lipoproteins and gluconeogenesis, resulting in dyslipidemia. In addition, high levels of plasma leptin activate the renin-angiotensin system and the sympathetic nervous system, causing sodium retention and vasoconstriction ${ }^{(11)}$.

Moreover, C-reactive protein was also deemed as a risk factor for MS. This inflammatory biomarker is associated with greater chance of mortality due to all causes, in addition to the cardiovascular, atherosclerosis and insulin resistance ${ }^{(31)}$. We emphasize that obesity itself leads to a proinflammatory and prothrombotic condition, enhancing the changes for atherosclerosis ${ }^{(11)}$. Authors of a population-based, prospective study conducted in Italy, entitled InChianti, on 1,044 older people ( $\geq 65$ years), demonstrated statistically significant association between MS and high CRP levels (OR: 1.93; 95\% Cl: 1.46-2.55) after adjustment for age, sex, and comorbidities in relation to their peers. In addition, median CRP values progressively increased from 2.40 $\mathrm{mg} / \mathrm{L}$, in subjects without MS, to $3.24,3.45$, and $5.07 \mathrm{mg} / \mathrm{L}$, in subjects with three, four, and five criteria for MS, respectively $(p<0.05)^{(34)}$.

Considering the findings, the integration of collective actions directed to community health must be incorporated in all levels of health care, in order to promote the adaptation to healthier behaviors in a population level. Healthcare professionals must be motivated to manage the risks and possible complications of the clinical pattern of patients, as well as encouraging changes in the lifestyle of the individuals, including weight reduction and following a healthy diet ${ }^{(4,33)}$.

However, the implementation of these actions is complex, to the extent having access to information about healthy lifestyle habits does not necessarily imply the greater participation of users in these practices. Thus, we found a gap between knowledge and practice, i.e., usually, even though knowing what should be done, users do not act in accordance with such knowledge, because they need to feel part of these actions and, therefore, motivated and confident in joining them. Furthermore, they should recognize and believe in the potential benefits that adopting healthy lifestyle habits can bring them ${ }^{(35)}$.

Particularly, this discussion is perceived differently when focusing on older adults, considered a major challenge to public health for two reasons. For instance, if we consider older adults with hypertension and dyslipidemia that knowingly have an excessive intake of fatty and salty foods. The first reason concerns older adults who lived through the excessive rates of premature deaths from these causes: probably, they are little motivated to reduce the intake of fats and salt, underestimating the risks. In addition, they consider themselves relatively immune to damages caused by this type of diet. The second reason refers to the passive conduct of healthcare professionals themselves, who tend not to engage in actions directed to the change of behavior, because usually, when considering the "advanced" age of patients, they do not want to deprive them of a source of pleasure, or other unhealthy behaviors such as excessive intake of alcoholic beverages and smoking ${ }^{(36)}$.

In this perspective, the nursing staff plays a fundamental role as a change promoter, empowering users to take control of managing their own health based on participatory attitudes, avoiding reducing health care to the healing logic, and creating models of completeness and humanization, especially in Primary Health Care (PHC), considered a privileged locus for the implementation of actions directed to the promotion of health and prevention of diseases or aggravations ${ }^{(37)}$.

\section{Study limitations}

As limitation of the study we highlight its cross-sectional quality, which makes impossible to determine causal relationships of the outcome and variables of interest. However, information on dyslipidemia and diabetes mellitus were obtained by the dosage of respective analytes, as well as hypertension and overweight/obesity, by measuring blood pressure and anthropometric measurements, which can contribute to ease the underestimation of such outcomes.

\section{Contributions to the field of nursing, health, or public policies}

This study reinforces the imperative need in maintaining, in a continuous and proactive way, the early detection of risk factors for MS, as well as its handling, in order to reduce its high prevalence among older adults from the multidisciplinary healthcare work, considering all the cycles of life. In this sense, we highlight the role of nurses, whose main tool is the nursing consultation, which should be seen not as a simple technical procedure, but as a rich context of interpersonal relationships, based on open and respectful communication with the users, considered in their completeness and particularities ${ }^{(38)}$.

\section{CONCLUSION}

In our study we found high prevalence of MS, as well as of clusters and its components, in older adults. Association of this syndrome with women, overweight/obesity, and high levels of C-reactive protein points to the need to deepen studies on MS, considering clinical aspects concerning sex and healthy behavioral habits, aiming to formulate public policies, as well as to emphasize actions aimed at early reduction of weight considering the global epidemic of obesity, promoting self-care and integrated actions, in such a way that all stages of the life cycle are contemplated.

\section{FUNDING}

This work received financial support from Fundação de Amparo à Pesquisa do Estado de Minas Gerais (Fapemig APQ 00108-11; APQ 02212-14 and APQ 03556-13) and from Coordenação de Aperfeiçoamento de Pessoal de Nível Superior (Capes). 


\section{REFERENCES}

1. Samson SL, Garber AJ. Metabolic syndrome. Endocrinol Metab Clin N Am [Internet]. 2014 [cited 2018 Apr 12];43(1):1-23. Available from: https://www.ncbi.nlm.nih.gov/pubmed/24582089

2. Pucci G, Alcidi R, Tap L, Battista F, Mattace-Raso F, Schillaci G. Sex- and gender-related prevalence, cardiovascular risk and therapeutic approach in metabolic syndrome: a review of the literature. Pharmacol Res [Internet]. 2017 [cited 2018 Jun 10];120:34-42. Available from: https://www.ncbi.nlm.nih.gov/pubmed/28300617

3. Ju S-Y, Lee J-Y, Kim D-H. Association of metabolic syndrome and its components with all-cause and cardiovascular mortality in the elderly. Medicine [Internet]. 2017 [cited 2018 Apr 20];96(45):e8491. Available from: https://www.ncbi.nlm.nih.gov/pubmed/29137039

4. Shin J-A, Lee J-H, Lim S-Y, Ha H-S, Kwon H-S, Park Y-M, et al. Metabolic syndrome as a predictor of type 2 diabetes, and its clinical interpretations and usefulness. J Diabetes Invest [Internet]. 2013 [cited 2018 Mar 15];4(4):334-43. Available from: https://www.ncbi.nlm.nih.gov/pubmed/24843675

5. Dragsbæk K, Neergaard JS, Laursen JM, Hansen HB, Christiansen C, Beck-Nielsen H, et al. Metabolic syndrome and subsequent risk of type 2 diabetes and cardiovascular disease in elderly women: challenging the current definition. Medicine [Internet]. 2016 [cited 2018 Apr 20];95(36):e4806. Available from: https://www.ncbi.nlm.nih.gov/pubmed/27603394

6. Ng TP, Feng L, Nyunt MSZ, Feng L, Gao Q, Lim ML, et al. Metabolic syndrome and the risk of mild cognitive impairment and progression to dementia: follow-up of the Singapore Longitudinal Ageing Study Cohort. JAMA Neurol [Internet]. 2016 [cited 2018 Apr 20];73(4):456-63. Available from: https://www.ncbi.nlm.nih.gov/pubmed/26926205

7. Moreira GC, Cipullo JP, Ciorlia LAS, Cesarino CB, Vilela-Martin JF. Prevalence of metabolic syndrome: association with risk factors and cardiovascular complications in an urban population. PLOS ONE [Internet]. 2014 [cited 2018 Jan 15];9(9):e105056. Available from: https:// www.ncbi.nlm.nih.gov/pubmed/25180496

8. Scuteri A, Laurent S, Cucca F, Cockcroft J, Cunha PG, Mañas LR, et al. Metabolic syndrome across Europe: different clusters of risk factors. Eur J Prev Cardiol [Internet]. 2015 [cited 2018 Mar 17];22(4):486-91. Available from: https://www.ncbi.nlm.nih.gov/pubmed/24647805

9. Moore JX, Chaudhary N, Akinyemiju T. Metabolic syndrome prevalence by race/ethnicity and sex in the United States, National Health and Nutrition Examination Survey, 1988-2012. Prev Chronic Dis [Internet]. 2017 [cited 2018 Apr 20];14:E24. Available from: https://www.ncbi. nlm.nih.gov/pubmed/28301314

10. Assunção N, Sudo FK, Drummond C, Felice FG, Mattos P. Metabolic syndrome and cognitive decline in the elderly: a systematic review. PLOS One [Internet]. 2018 [cited 2018 May 23];13(3):e0194990. Available from: https://www.ncbi.nlm.nih.gov/pubmed/29579115

11. Kaur J. A comprehensive review on metabolic syndrome. Cardiol Res Pract [Internet]. 2014 [cited 2018 Apr 20];2014:943162. Available from: https://www.ncbi.nlm.nih.gov/pubmed/24711954

12. Havakuk O, Perl ML, Praisler O, Barkagan M, Sadeh B, Margolis G, et al. The awareness to metabolic syndrome among hospital health providers. Diabetes Metab Syndr [Internet]. 2017 [cited 2018 Apr 20];11(3):193-7. Available from: https://www.ncbi.nlm.nih.gov/ pubmed/27707551

13. Felipe-de-Melo ERT, Silva RCR, Assis AMO, Pinto EJ. [Factors associated with metabolic syndrome in administrative workers in the oil industry]. Ciênc Saúde Colet [Internet]. 2011 [cited 2018 Apr 20];16(8):3443-52. Available from: http://www.scielo.br/pdf/csc/v16n8/a12v16n8.pdf Portuguese.

14. Moura DJM, Bezerra STF, Moreira TMM, Fialho AVM. [Nursing care to the client with hypertension: a bibliographic review]. Rev Bras Enferm [Internet]. 2011 [cited 2018 Mar 13];64(4):759-65. Available from: http://www.scielo.br/pdf/reben/v64n4/a20v64n4.pdf Portuguese.

15. Hildrum B, Mykletun A, Hole T, Midthjell K, Dahl AA. Age-specific prevalence of the metabolic syndrome defined by the International Diabetes Federation and the National Cholesterol Education Program: the Norwegian HUNT 2 study. BMC Public Health [Internet]. 2007 [cited 2018 Apr 20];7:220. Available from: https://www.ncbi.nlm.nih.gov/pubmed/17727697

16. Ministério da Saúde (BR). Resolução CNS/MS no 466, de 12 de dezembro de 2012. Diário Oficial da União [Internet]. 2013 Jun 13 [cited 2018 Oct 22];1:59. Available from: http://bvsms.saude.gov.br/bvs/saudelegis/cns/2013/res0466_12_12_2012.html

17. Silva LB, Soares SM, Silva PAB, Santos JFG, Miranda LCV, Santos RM. Assessment of the quality of primary care for the elderly according to the Chronic Care Model. Rev Latino-Am Enfermagem [Internet]. 2018 [cited 2018 Apr 15];26:e2987. Available from: https://www.ncbi.nlm. nih.gov/pubmed/29538582

18. Brasil, Presidência da República, Casa Civil, Subchefia para Assuntos Jurídicos. Lei no 10.741 , de $1^{\circ}$ de outubro de 2003. Dispõe sobre o Estatuto do Idoso e dá outras providências. Diário Oficial da União [Internet]. 2003 Oct 3 [cited 2018 Apr 15];1:1. Available from: http://www. planalto.gov.br/ccivil_03/LEIS/2003/L10.741.htm

19. Lwanga SK, Lemeshow S. Sample size determination in health studies: a practical manual. Geneva: WHO; 1991.

20. Grundy SM, Cleeman JI, Daniels SR, Donato KA, Eckel RH, Franklin BA, et al. Diagnosis and management of the metabolic syndrome an American Heart Association/National Heart, Lung, and Blood Institute Scientific Statement. Circulation [Internet]. 2005 [cited 2018 Apr 20];112:2735-52. Available from: https://www.ncbi.nlm.nih.gov/pubmed/16157765

21. Lira Neto JCG, Xavier MA, Borges JWP, Araújo MFM, Damasceno MMC, Freitas RWJF. Prevalence of metabolic syndrome in individuals with type 2 diabetes mellitus. Rev Bras Enferm [Internet]. 2017 [cited 2018 Apr 17];70(2):265-70. Available from: http://www.scielo.br/pdf/reben/ v70n2/0034-7167-reben-70-02-0265.pdf 
22. Bush K, Kivlahan DR, McDonell MB, Fihn SD, Bradley KA. The AUDIT alcohol consumption questions (AUDIT-C): an effective brief screening test for problem drinking. Ambulatory Care Quality Improvement Project (ACQUIP). Arch Intern Med [Internet]. 1998 [cited 2018 Apr 20];158(16):1789-95. Available from: https://www.ncbi.nlm.nih.gov/pubmed/9738608

23. Bertolucci PHF, Brucki SMD, Campacci SR, Juliano Y. O mini-exame do estado mental em uma população geral. Impacto da escolaridade. Arq Neuropsiquiatr [Internet]. 1994 [cited 2018 Apr 20];52(1):1-7. Available from: http://www.scielo.br/pdf/anp/v52n1/01.pdf

24. Lipschitz DA. Screening for nutritional status in the elderly. Prim Care [Internet]. 1994 [cited 2018 Apr 18];21(1): 55-67. Available from: https://www.ncbi.nlm.nih.gov/pubmed/8197257

25. Vieira EC, Peixoto MRG, Silveira EA. Prevalence and factors associated with Metabolic Syndrome in elderly users of the Unified Health System. Rev Bras Epidemiol [Internet]. 2014 [cited 2018 Apr 20];17(4):805-17. Available from: http://www.scielo.br/pdf/rbepid/v17n4/1415790X-rbepid-17-04-00805.pdf

26. Saad MAN, Cardoso GP, Martins WA, Velarde LGC, Cruz Filho RA. Prevalence of metabolic syndrome in elderly and agreement among four diagnostic criteria. Arq Bras Cardiol [Internet]. 2014 [cited 2018 Apr 20];102(3):263-9. Available from: http://www.scielo.br/pdf/abc/v102n3/ en_0066-782X-abc-20140013.pdf

27. Alemán-Mateo H, López Teros MT, Urquidez-Romero R, Huesca L. Prevalence of metabolic syndrome and its determinants in older Mexican non-diabetic adults. Nutr Hosp [Internet]. 2018 [cited 2018 Apr 20];35(2):294-304. Available from: https://www.ncbi.nlm.nih.gov/ pubmed/29756961

28. Raposo L, Severo M, Barros H, Santos AC. The prevalence of the metabolic syndrome in Portugal: the PORMETS study. BMC Public Health [Internet]. 2017 [cited 2018 Apr 20];17(1):555. Available from: https://www.ncbi.nlm.nih.gov/pubmed/28595618

29. Yusuf S, Hawken S, Ounpuu S, Dans T, Avezum A, Lanas F, et al. Effect of potentially modifiable risk factors associated with myocardial infarction in 52 countries (the INTERHEART study): case-control study. Lancet [Internet]. 2004 [cited 2018 Apr 20];364(9438):937-52. Available from: https://www.ncbi.nlm.nih.gov/pubmed/15364185

30. Sung KC, Rhee EJ, Ryu S, Kim BJ, Kim BS, Lee WY, et al. Increased cardiovascular mortality in subjects with metabolic syndrome is largely attributable to diabetes and hypertension in 159,971 Korean adults. J Clin Endocrinol Metab [Internet]. 2015 [cited 2018 Apr 20];100(7):2606-12. Available from: https://www.ncbi.nlm.nih.gov/pubmed/25993638

31. Tsai SS, Lin YS, Hwang JS, Chu PH. Vital roles of age and metabolic syndrome-associated risk factors in sex-specific arterial stiffness across nearly lifelong ages: possible implication of menopause and andropause. Atherosclerosis [Internet]. 2017 [cited 2018 Apr 20];258:26-33. Available from: https://www.ncbi.nlm.nih.gov/pubmed/28182996

32. NCD Risk Factor Collaboration (NCD-RisC). Trends in adult body-mass index in 200 countries from 1975 to 2014: a pooled analysis of 1698 population-based measurement studies with 19.2 million participants. Lancet [Internet]. 2016 [cited 2018 Apr 20];387:1377-96. Available from: https://www.ncbi.nlm.nih.gov/pubmed/27115820

33. Malta DC, Andrade SC, Claro RM, Bernal RTI, Monteiro CA. Trends in prevalence of overweight and obesity in adults in 26 Brazilian state capitals and the Federal District from 2006 to 2012. Rev Bras Epidemiol [Internet]. 2014 [cited 2018 July 20];17(Suppl 1):267-76. Available from: http://www.scielo.br/pdf/rbepid/v17s1/1415-790X-rbepid-17-s1-00267.pdf

34. Zuliani G, Volpato S, Galvani M, Blè A, Bandinelli S, Corsi AM, et al. Elevated C-reactive protein levels and metabolic syndrome in the elderly: the role of central obesity data from the InChianti study. Atherosclerosis [Internet]. 2009 [cited 2018 Apr 20];203(2):626-32. Available from: https://www.ncbi.nlm.nih.gov/pubmed/18845301

35. Silva LB, Souza KV, Duarte ED, Soares SM. [Epistemological settings of care in health and nursing according to Halldorsdottir's Theory]. Rev Cuidarte [Internet]. 2016 [cited 2018 Apr 20];7(2):1358-65. Available from: https://www.revistacuidarte.org/index.php/cuidarte/article/ view/333 Portuguese.

36. Zaitune MPA, Barros MBA, Lima MG, César CLG, Carandina L, Goldbaum M, et al. [Factors associated with smoking in the elderly: a health survey in São Paulo (ISA-SP)]. Cad Saúde Pública [Internet]. 2012 [cited 2018 Jan 22];28(3):583-95. Available from: http://www.scielo.br/pdf/ csp/v28n3/18.pdf Portuguese.

37. Backes DS, Backes MS, Erdmann AL, Büscher A. [The role of the nurse in the Brazilian Unified Heath System: from community health to the family health strategy]. Ciênc Saúde Colet [Internet]. 2012 [cited 2018 Apr 20];17(1):223-30. Available from: http://www.scielo.br/pdf/csc/ v17n1/a24v17n1.pdf Portuguese.

38. Silqueira SMF, Lima MP, Cunha DCP, Lemos ACSF, Pereira JR, Lima PL. [The nursing process as a strategy for changes in the lifestyle of patients with hypertension]. Rev Min Enferm [Internet]. 2007 [cited 2018 Apr 20];11(3):331-7. Available from: http://www.reme.org.br/ artigo/detalhes/355 Portuguese. 